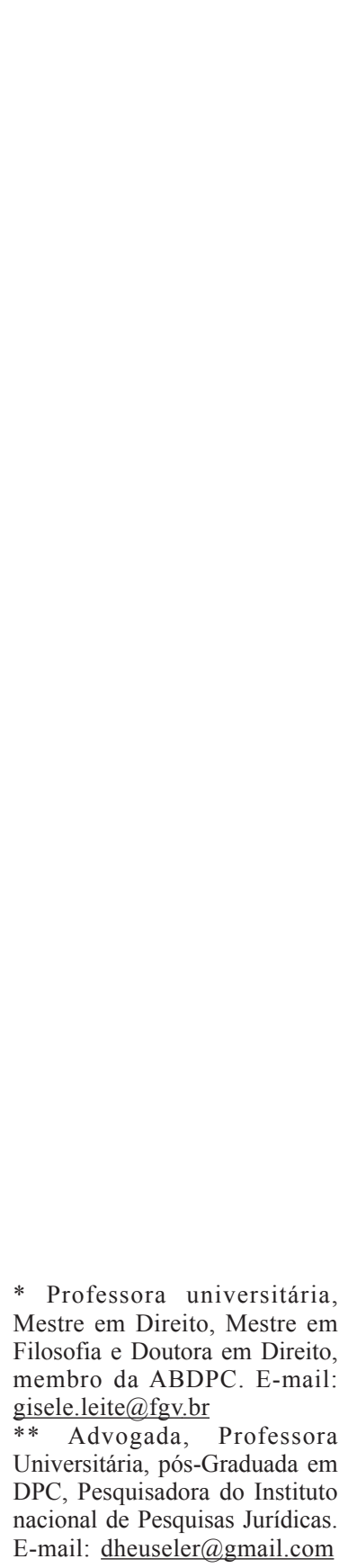

\section{Considerações principiológicas sobre a Constituição Federal Brasileira}

\section{Principiologic Considerations about Brazilian Federal Constitution}

\author{
Gisele Leite * \\ Denise Heusler **
}

Resumo: $\mathrm{O}$ artigo expõe didaticamente a carga principiológica do atual texto constitucional vigente no Brasil. Analisando o sentido interpretativo, doutrinário e jurisprudencial.

Palavras-Chave: Direito Constitucional. Constitucionalismo. Princípios Constitucionais.

Abstract: The article exposes didactically principled load the current constitution in force in Brazil. Analyzing the interpretative, doctrinal and jurisprudential.

Keywords: Constitutional Law. Constitutionalism. Constitutional Principles. 


\section{INTRODUÇÃO}

Num primeiro momento, procuramos humildemente o conceito de Constituição principalmente por ser alvo de tantas discussões científicas e, por ser amplíssimo seu conteúdo apesar de ser bem concreta sua estrutura. A insuficiência do conceito formal de constituição é patente e segundo a doutrina entende-se por constituição aquele conjunto de princípios que se situam no vértice de qualquer sistema normativo, relativos a um número variado de entes, tais como os Estados, as organizações internacionais, a comunidade internacional (BOBBIO, 2004, p.259).

Há ainda um sentido político de Constituição desenvolvido por Carl Schmitt que significa o conjunto das decisões fundamentais sobre o modo e forma de existência da unidade de poder.

Ferdinand Lassalle sustenta que a Constituição é algo situado no mundo de ser, é dizer que a Constituição é o reflexo das relações de poder que se interagem em uma determinada comunidade política informando todas as leis e instituições jurídicas nesta existente. Cunhou o conhecido conceito sociológico de Constituição ao estabelecer que tal documento deve descrever rigorosamente a realidade política do país, sob pena de não ter efetividade, tornando-se um mera folha de papel. Esse conceito nega que a Constituição possa mudar a realidade.

Constituição etimologicamente advém do latim constitutio, de constituere (constituir, construir, formar, organizar); no sentido do Direito Público, possui significação elevada: designa o conjunto de regras e preceitos, princípios que se reconhecem como fundamentais estabelecidos pela soberania de um povo, para servir de base à sua organização política e firmar os direitos e deveres de cada um de seus componentes.

É a Lei Magna de um povo politicamente organizado, desde que nesta se assentem todas as bases do regime escolhido, fixando as relações recíprocas entre governantes e governados. Estabelece todas as formas necessárias para delimitar a competência de poderes públicos, impondo as regras de ação das instituições públicas e as restrições que devem ser adotadas para garantia dos direitos individuais.

Salienta com razão Eduardo Garcia de Enterría (1986, p.37) que “[...] a Constituição não é apenas uma norma, senão precisamente a primeira das normas do ordenamento inteiro, a norma fundamental, a lex superior." Isso porque a Constituição define o sistema de fontes formais do direito, é a norma 
nomarum, a fonte das fontes. A Constituição é expressão de uma intenção fundacional configuradora de um sistema inteiro que nesta se baseia, tem uma pretensão de permanência ou duração e de superioridade.

Curioso é o posicionamento de Gustav Radbruch que se tornou defensor do direito natural após 1945 (do qual antes era ferrenho opositor). No prólogo de sua obra Arbitrariedade Legal y Derecho Supralegal o comentário de María Isabel Azaretto de Vásquez:

A experiência nacionalsocialista produz uma tal impressão nele, que o obriga a repensar seu anterior positivismo, e esta reflexão o leva a rechaçá-lo, já que vê na separação do direito e da moral a base em que se apoiou o nazismo para levar a cabo, sob a aparência de legalidade, as maiores injustiças. A formação positivista dos juízes e advogados os inabilitou para defender-se contra a legalidade injusta. Isto leva a Radbruch a sustentar que uma lei que contrarie os princípios básicos da moralidade não é direito, ainda que seja "formalmente válida. O positivismo desarmou de fato aos juristas alemães frente a leis de conteúdo arbitrário e delitivo. O positivismo ademais, não está em condições de fundamentar com suas próprias forças a validade das leis. A ideia de direito não pode ser diferente da ideia de Justiça. (1962, p.5).

A Constituição é constituída de normas jurídicas imperativas autorizantes. Não podemos, porém, nos contentar com o conceito de Kelsen devido ao seu aspecto exageradamente reducionista.

Mas lembremos que a Constituição é norma jurídica, mas a esta não se reduz, é conveniente adotarmos o conceito tridimensional, posto que mais adequado à dimensão axiológica de documento legal.

Desta forma, a Constituição se revela um conjunto de normas jurídicas disciplinadoras do exercício do poder político, estatui a ordem fundamental jurídica da coletividade. É preciso lembrar que o Direito é um fenômeno cultural e, como tal, afasta-se radicalmente das ciências ditas naturais, visto que, quanto a estas, as conclusões obtidas se revestem das verdades resultantes do método empírico-indutivo a que se submetem as realidades próprias das ciências naturais.

Assim, a Constituição é sede de determinadas categorias de normas que refogem à estrutura típica das normas dos demais ramos do Direito. Citemse as normas determinadoras de competências, as normas de organização, as normas de garantias de direitos fundamentais e as normas programáticas.

Traz em seu bojo os valores fundamentais, perseguidos pela sociedade, é norma limitadora do poder político, e também asseguradora dos direitos 
fundamentais individuais (que foram particularmente conquistados no final do século XVIII pelo movimento chamado constitucionalismo). Direitos tais como a liberdade, a igualdade, propriedade, segurança e vida; direitos sociais (relativos à educação, trabalho, lazer, seguridade social entre outros), direitos econômicos (relativos ao pleno emprego, meio ambiente e consumidor) e direitos políticos (relativos às formas de realização da soberania popular).

\section{NEOCONSTITUCIONALISMO E O PAPEL DOS PRINCÍPIOS}

O constitucionalismo contemporâneo representa a superação da visão de que a lei por excelência é a solução para todos os problemas e, por conseguinte, deve ser seguida incondicionalmente. Já na linha do positivismo crítico que analisa que não se pode mais dissociar a realidade social que os rodeiam, surgiram com ênfase, em quase todo mundo, logo após a Segunda Grande Guerra Mundial.

Note-se que as Constituições escritas, diferentemente dos Códigos, vieram impregnadas de prescrições que traduzem valores, conduzindo a uma releitura da sua forma de aplicação e ao mesmo tempo condicionando toda a atuação estatal.

Num primeiro momento da evolução das constituições vê-se que estas representavam politicamente a massificação do pensamento de certa classe dominante, como enunciava Ferdinand Lassalle.

Revista, sua força normativa incorporou-se e ampliou-se aos textos constitucionais, evoluindo para o constitucionalismo ao início de uma nova fase, conforme afirma Konrad Hesse.

Sendo muito relevante na teoria do Direito e nas constituições contemporâneas, a afirmação da força normativa dos princípios constitucionais impôs a superação das correntes teóricas que ainda sustentavam um direito formado apenas por regras estritas, vistas como únicos preceitos dotados de juridicidade.

Bem explicou Luiz Guilherme Marinoni (2006) que: “[...] a lei perdeu sua supremacia absoluta e hoje é subordinada à Constituição. Professa-se o slogan corrente que as leis devem estar em conformidade com os direitos fundamentais, contrariando o que antes acontecia, quando os direitos fundamentais dependiam da lei."

A assunção do Estado constitucional deu novo conteúdo ao princípio da legalidade que então agregou o qualificativo "substancial" para evidenciar que 
exige a conformação da lei com a Constituição e, especialmente com os direitos fundamentais.

Em verdade, o princípio da legalidade substancial significa uma "transformação" que afeta as próprias concepções de direito e de jurisdição e, desta forma, representa uma ruptura de paradigma.

A Constituição ideal é aquela que reflete os desígnios da unidade política a esta subjacente, correspondente ao conjunto de normas superiores elaboradas pelo Poder Constituinte, cuja titularidade pertença ao povo e tem por objeto não a criação e regulamentação dos poderes constituídos, bem como, o estabelecimento de direitos e garantias fundamentais individuais e coletivas.

Pretende a Constituição ser norma duradora, além de social e juridicamente eficaz, devendo ter atualização dinâmica, por isso, sofre reformas constitucionais, porém tal compulsão reformista pode acarretar a banalização da supremacia da Constituição.

Evidentemente a Constituição deve revitalizar sua força normativa por meio da interpretação constitucional. A Constituição é, como acentua Pontes de Miranda (1967), “[...] o conjunto de regras jurídicas onde as forças políticas encontram o seu leito, o seu equilíbrio". É, em suma, o estatuto jurídico-político do Estado. Vige certo consenso sobre a normatividade dos princípios jurídicos constitucionais, e nesse sentido, ratifica Larenz, pois assinala o seu alto teor de generalidade e abstração. A Ciência do Direito, por longo tempo, somente se preocupou com a normatividade, segundo os adeptos do positivismo que fora inspirado fortemente das ciências naturais. Assim o dogma da neutralidade, objetividade e universalidade das ciências naturais que é também discutível não pode ser impunemente transferido pela ciência do Direito. Karl Larenz (1983), mencionando como a teoria pura do direito muito influenciou o nosso atual pensamento jurídico, esclarece: "Por esta razão, e também pelo sentimento de que a autonomia da ciência do Direito vinha assim perder-se em benefício de outras ciências (principalmente psicologia ou a sociologia), é que Kelsen, por último, na sua Teoria Pura do Direito reivindica para a ciência jurídica à semelhança da lógica e da matemática, um objeto puramente ideal, restringindo ao simples campo do racionalmente necessário (...).” A teoria de Karl Larenz sobre interpretação jurídica tem como pressuposto a necessidade da interpretação das normas, a qual deriva de situações de fato problemáticas quanto à compreensão do sentido e alcance do texto da norma, como, por exemplo, quando o intérprete da lei se vê diante de conceitos/palavras que comportam mais de um sentido ou quando verifica que há uma espécie de 
conflito de normas que potencialmente regulam a mesma situação fática, mas em sentidos totalmente contrários.

Por isso, precisam de sucessivas concretizações de modo que os princípios mais generalistas são especificados em outros subprincípios, até que atinjam o grau necessário à sua aplicação.

Os princípios se apresentam como uma ideia jurídica geral ou diretiva que serve de base e direção para a sua concretização futura, atuando como um verdadeiro fio condutor. O princípio se esclarece por meio de suas concretizações e estas ganham significado quando voltadas a este numa autêntica atividade de esclarecimento recíproco.

Devido ao seu alto grau de abstração, os princípios não são inteiramente capazes de subsunção e, consequentemente, não podem ser aplicados de forma imediata, a menos que haja a sua concretização por meio de outros subprincípios e de valores singulares com material próprio. Desta forma, necessitam normatização, caso queiram incidir na realidade fática para ordenar condutas. Os princípios esquadrinham uma tábua valorativa e atuam como autênticas normas jurídicas.

Paulo Bonavides (2000) aponta o desenvolvimento do conceito de princípios em três fases distintas: a jusnaturalista, a juspositivista e a póspositivista.

O jusnaturalista condiciona a legitimidade da ordem jurídica elaborada pelo Estado à outra ordem superior e transcendental. Pois acima das leis humanas existe o Direito Natural para lhe conferir suporte axiológico voltado para determinado valor reputado como fundamental. É a doutrina que reconhece a existência de um direito natural, que tem validade em si e é anterior e superior ao direito positivo, devendo prevalecer caso haja um conflito entre as normas do direito positivo e as do direito natural. Todo jusnaturalista, portanto, defende duas teses: a dualidade (existem duas manifestações do direito, o positivo e o natural) e a superioridade ( $\mathrm{O}$ direito natural é superior ao positivo). $\mathrm{O}$ jusnaturalismo contemporâneo deitou raiz após a Segunda Grande Guerra Mundial, por se basear em valores morais, e surgiu como boa solução para o cenário formado, pois existia a necessidade de controle do Estado, o que culminou com a criação da ONU. Havia a consciência de que não existiam valores morais universais, de maneira que a nova geração de jusnaturalistas considerava o direito natural como histórico, e não como universal e imutável, ou seja, foram abertas concessões quanto ao conceito de direito natural. Severas críticas ao renascimento do jusnaturalismo surgiram, principalmente por escapar ao modelo 
positivista e ainda por ampliar muito o poder ao juiz, o que nos leva dois sérios busilis: a) a insegurança jurídica e; b) a ruptura da tripartição dos poderes, pois afinal o judiciário acabaria por legislar.

No jusnaturalismo, os princípios estão na ordem supralegal, de tal maneira que não integram o direito posto criado pelos agentes estatais. Direito natural (em latim ius naturali) ou jusnaturalismo é uma teoria que postula a existência de um direito cujo conteúdo é estabelecido pela natureza e, portanto, válido em qualquer lugar. A expressão "direito natural" é por vezes contrastada com o direito positivo de uma determinada sociedade, o que lhe permite ser usado, por vezes, para criticar o conteúdo daquele direito positivo. Para os jusnaturalistas (isto é, os juristas que afirmam a existência do direito natural), o conteúdo do direito positivo não pode ser conhecido sem alguma referência ao direito natural. A teoria do direito natural abrange uma grande parte da filosofia de Tomás de Aquino, Francisco Suárez, Richard Hooker, Thomas Hobbes, Hugo Grócio, Samuel von Pufendorf, John Locke e Jean-Jacques Rousseau, e exerceu uma influência profunda no movimento do racionalismo jurídico do século XVIII, quando surge a noção dos direitos fundamentais, no conservadorismo, e no desenvolvimento da common law inglesa.

Entretanto, os princípios sumarizam valores máximos que correspondem à ideal de justiça e de direito, assumindo as características do Direito Natural (que guardam identificação axiomática com valores universais advindos da natureza humana e revelados à luz da reta razão).

Já na fase positivista, segundo o autor (BONAVIDES, 2000), os princípios estão insertos no ordenamento jurídico positivo, fazendo parte dele. Assim dentro do positivismo, a lei possui verdadeira primazia e os princípios ocupam um lugar secundário, servindo tão somente em caso de eventuais vazios normativos desempenhando função meramente supletiva na aplicação do direito. Surgia o positivismo. Nesta fase, tinha-se a pretensão de criar uma Ciência Jurídica com objetividade científica e características similares das conferidas às Ciências Exatas. Apartava-se, assim, o Direito da Moral, de modo a inseri-los em compartimentos estanques para fins científicos.

Por se situarem na esfera tão abstrata e distante, os princípios possuem uma normatividade basicamente nula e duvidosa, daí carecerem de carga vinculatória. Exatamente no pós-positivismo, os princípios jurídicos deixam de possuir apenas a função integratória do direito, conquistando o status de normas jurídicas vinculantes. 
Os princípios jurídicos muito se aproximam daquilo que em doutrina pátria chamamos de princípios gerais de direito.

Resta evidente a partir do disposto no art. $4^{\circ}$ da Lei de Introdução do Código Civil, que data de 1942 e apontava o papel essencialmente supletivo dos princípios gerais de direito.

Os princípios gerais do Direito, classificados por Miguel Reale (1997) como monovalentes, são enunciações normativas de valor genérico, que condicionam e orientam a compreensão do ordenamento jurídico em sua aplicação e integração ou mesmo para a elaboração de novas normas. Os princípios gerais do direito são os alicerces do ordenamento jurídico, informando o sistema independentemente de estarem positivados em norma legal. São exemplos: Falar e não provar é o mesmo que não falar; Ninguém pode causar dano, e quem causar terá que indenizar; Ninguém pode se beneficiar da própria torpeza; Ninguém deve ser punido por seus pensamentos; Ninguém é obrigado a citar os dispositivos legais nos quais ampara sua pretensão, pois se presume que o juiz os conheça; Ninguém está obrigado ao impossível; Não há crime sem lei anterior que o descreva.

Os princípios gerais do direito dentro do contemporâneo acabam por assumir nova roupagem e galgaram status constitucional.

Vejamos como exemplos recentes a função social da propriedade, da posse, da empresa, do contrato, a boa-fé objetiva na esfera obrigacional e contratual, tudo no sentido de garantir o mínimo ético. Significa que o Direito representa apenas o mínimo de moral declarado obrigatório para que possa a sociedade sobreviver.

Tais princípios gerais do direito sofreram flagrante processo de constitucionalização e transmudaram-se em princípios constitucionais.

[...] O movimento de constitucionalização dos princípios jurídicos coincide com a formulação da teoria normativista dos princípios, em contraposição às ideias positivistas que dominaram o raciocínio jurídico até a metade do século $\mathrm{XX}$. O uso dos princípios como fonte normativa subsidiária, conforme defendido pelo positivismo jurídico, já não encontra mais guarida na moderna teoria constitucional. (CRISTÓVAM, 2003).

Atualmente no pensamento jurídico contemporâneo na etapa chamada "pós-positivista" os princípios assumem normatividade máxima, possuindo status conceitual e positivo de norma jurídica. A queda do positivismo coincide com a época em que o homem passou a se preocupar mais com os direitos sociais, 
atribuindo uma dimensão superior à necessidade de se solucionar conflitos independentemente das leis. Viu-se que não é sempre que a lei é legítima, ou seja, que a norma corresponde à vontade social. A estimação exasperada à lei fria, consequentemente, passou a granjear justas críticas, encontrando no Brasil defensores da irrestrita relação entre diferentes elementos: o fato social, o valor, e, é óbvio, a norma jurídica (Miguel Reale e outros).

No remanescente do mundo, outros pensadores, como Ronald Dworkin e F. Muller, passaram a sustentar, apesar de algumas adjacências, as mesmas ideias-base. Era o início do pós-positivismo jurídico. A nova fase passou a atribuir maior importância não somente às leis, mas aos princípios do direito. E os princípios, analisados como espécies de normas, tinham, ao contrário das regras, ou leis, um campo maior de abrangência, pois se tratavam de preceitos que deveriam intervir nas demais normas, inferiores, para obter delas o real sentido e alcance. Tudo se ressalte, para garantir os direitos sociais do homem.

Concluiu-se que possuem positividade vinculativa com eficácia positiva e negativa sobre os comportamentos públicos ou privados, as recentes Constituições Federais promulgadas bem acentuam a hegemonia axiológica dos princípios, convertidos em pedestal normativo sobre o qual se assenta todo o edifício jurídico dos novos sistemas constitucionais (BONAVIDES, 1994, p.237).

No pós-positivismo, os princípios são mais que meras diretrizes a serem perseguidas ou não pelos seus destinatários; não são simples recomendações utilizáveis na ocasião de insuficiência regulatória dos diplomas legais. São efetivamente normas jurídicas que impõem um dever-ser, dotados de cogência e imperatividade, especialmente quando asseguram direitos fundamentais.

Aristóteles (apud PEIXINHO, 2003, p.123) foi um dos primeiros a enumerar os significados de princípios, quais sejam: 1) ponto de partida de um movimento (uma linha ou estrada); 2) o melhor ponto de partida pois torna mais fácil aprender uma coisa; 3 ) ponto de partida efetivo de uma produção (a quilha de navio ou alicerces de uma casa); 4) causa externa de um processo ou movimento (um insulto que provoca uma briga); 5) o que a sua decisão determina movimentos ou mudanças (governo ou magistraturas de uma cidade); 6) aquilo do qual parte um processo de conhecimento (as premissas de demonstração).

Justifica-se então o porquê os vários textos constitucionais se tornaram um autêntico habitat de normas jurídicas principiológicas com grande elasticidade e abertura, mais adaptáveis e atualizáveis em face das transformações sociais. 
Não apenas os princípios expressos são relevantes, mas igualmente os princípios implícitos e estes são igualmente considerados como normas jurídicas. Tais princípios implícitos decorrem da própria sistemática lógica arquitetada por todo ordenamento constitucional e também são dotados de normatividade. Portanto, sejam explícitos ou implícitos os princípios possuem definitivamente a mesma supremacia jurídica das demais normas.

A sociedade caracterizada pela diversidade e pluralidade assenta suas bases nos ideais democráticos e valores heterogêneos que muitas vezes se revelam contraditórios ou concorrentes e que, tomados no corpo da norma fundamental, possuem juridicidade constitucional.

A Constituição representa depositário de ideologias e convicções que devem ser respeitadas como corolário do Estado Democrático de Direito consagrador da igualdade jurídico-substancial.

Em face da velocíssima dinâmica sociocultural a Constituição tem como elemento um regulatório normativo básico, daí dever apresentar certa elasticidade e abertura no feito de proporcionar o devido acompanhamento das inovações advindas da estrutura social moderna e da complexidade das relações humanas.

\section{A FORÇA NORMATIVA DOS PRINCÍPIOS CONSTITUCIO- NAIS}

É cediça a noção de que os princípios são verdadeiras normas jurídicas de maneira que diferença entre estes e as regras jurídicas em sua acepção tradicional, é uma diferença entre duas espécies de normas, posto que ambos impõem um dever-ser. Eis, pois, a premissa do atual pensamento jusconstitucionalista.

Em termos mais práticos, o próprio Canotilho aponta duas dimensões determinantes dos princípios: uma negativa e outra positiva. $\mathrm{Na}$ primeira os princípios estabelecem uma proibição de conduta, enquanto na segunda, ao contrário, impõe um determinado comportamento. Nesse sentido, a transgressão de uma dessas dimensões quer negativa ou positiva, é fonte de nascimento de direito subjetivo ao sujeito lesado, restando, perfeitamente delimitado a aplicação imediata dos princípios jurídicos podendo levar a invalidação do ato jurídico praticado, seja uma sentença, ato administrativo ou até mesmo de uma lei.

Para ele, as diferenças entre princípios e regras seriam:

a) grau de abstração - possuem maior abstração os princípios, ao passo que as regras possuem inferior grau de abstração; 
b) grau de determinabilidade na aplicação no caso concreto, os princípios requerem mediações para serem aplicados, enquanto que as regras podem ser aplicadas diretamente;

c) caráter de fundamentabilidade no sistema das fontes do Direito, onde os princípios possuem papel fundamento no ordenamento jurídico, por causa de sua posição hierárquica superior dotado de força estruturante nos sistemas jurídicos;

d) proximidade da ideia de direito - os princípios são standards juridicamente vinculantes, decorrente de exigência de "justiça", enquanto que as regras podem ter um conteúdo meramente funcional;

e) natureza normogenética posto que os princípios sejam os fundamentos das regras.

Assim a generalidade das regras difere das dos princípios: aquelas são gerais na medida em que fixadas com o fim de reger número indeterminado de fatos ou atos, mas estas regem apenas esses fatos ou atos, pois que se referem uma situação jurídica determinada. Os princípios, de outra sorte, comportam uma série indefinida de aplicações.

Em suma, os princípios em sua generalidade e abstração tendem a abarcar um maior número de questões de fato. Evidentemente os princípios podem ser concretizados em normas mais específicas.

É fato que os princípios constitucionais são normas que ocupam o mais alto patamar na ordem normativa e, fundamentando todas as demais normas de escalão inferior, não poderiam ser preteridos em sua aplicação para beneficiar normas infraconstitucionais, que buscam na Constituição sua razão de existir.

Como normas que são, os princípios podem formular uma obrigação, faculdade ou proibição. Não são simples pautas valorativas e incapazes de oferecer soluções concretas a litígios.

Os preceitos constitucionais são normas diretamente vinculantes e, salvo as hipóteses de seus limites fático-jurídicos, podem encerrar razões para juízos concretos de dever-ser.

Dworkin (1985) aponta a diferenciação pautada na lógica. Tanto as regras quanto os princípios são standards que, em direções diversas, indicam decisões particulares concernentes às obrigações jurídicas sob certas circunstâncias. A literatura jurídica vem se esforçando no caloroso debate a respeito do tema, em razão da euforia do que poderíamos denominar Estado Principiológico. De acordo com Humberto Bergmann Ávila (apud CAVALCANTI, 2011), tratar-se-ia da nova postura dos legisladores que, ao incorporarem dispositivos essencialmente 
axiológicos, possibilitam ao intérprete uma postura com base nos preceitos, e não taxativamente na lei. Entretanto, ainda encontramos algumas indefinições terminológicas que certamente confundem a hermenêutica e sua aplicabilidade. O questionamento torna-se mais adequado quando se indaga: qual o verdadeiro sentido e alcance da distinção entre Valores, Regras e Princípios? Para que servem? Não se trata de um mero preciosismo linguístico?

Alega Dworkin (1985) que as regras são aplicadas sob forma de "disjuntivas"; verificam-se os fatos previstos na regra e esta será reputada válida, quando então poderá ser aplicada. Caso contrário, será inválida e não aplicável. Segue-se o critério do tudo ou nada.

Os princípios apresentam uma dimensão que carece existir nas regras, qual seja a de peso ou de importância.

Não pretendem os princípios delimitar exaustivamente as condições em que serão aplicados, apenas indicar uma direção, mas poderá haver mais de um princípio incidental na mesma situação, e até acenando para uma decisão oposta na inicial, de modo que será sempre necessário avaliar o peso de cada princípio envolvido, a fim de determinar qual deverá ser aplicado.

Sobre os critérios de resolução de antinomias (choque de regras), esclarece Norberto Bobbio que, em nível constitucional, esses instrumentos (cronológico, hierárquico e o da especialidade) serão de pouca valia, porque, com exceção do critério da especialidade - que não acarreta a anulação de uma regra -, os demais implicam a expulsão da norma oposta do sistema jurídico. A Constituição possui, esclarece Bobbio, uma função de propaganda e de educação política. É o que facilmente se verifica nas Constituições de elevado conteúdo ideológico, como as francesas da Revolução, as socialistas e as islâmicas, cujo texto contém, não só normas organizativas, mas sobretudo princípios de orientação e estímulos de ativação das massas.

Predomina na doutrina constitucionalista e na jurisprudência do STF a impossibilidade de aferição da validade dessas normas, uma vez que vige o principio da unidade da Constituição, de modo que ela é um complexo normativo orgânico e coerente, exigindo assim, a eliminação das tensões normativas que eventualmente nela apareçam (SARMENTO, 2003, p.27 passim).

No que se refere à colisão dos princípios, o intérprete aplicador deverá verificar as circunstâncias fáticas presentes no caso concreto para saber qual é o princípio que deverá ser privilegiado naquele momento. Alexy, em sua obra Teoria de los Derechos Fundamentales, apresenta a Lei de Colisão para solucionar a colisão de princípios utilizando um julgado do tribunal constitucional, 
que diz respeito à não realização da audiência oral tendo em vista a saúde delicada do acusado que sofre risco de infarto. Neste caso, há uma colisão entre o principio da aplicação do direito penal (P1 - que obriga a audiência oral) com o princípio de proteção do direito à vida e integridade do acusado (P2 - que proíbe a audiência oral).

A ponderação por um ou outro princípio só poderá ser feita à luz da situação concreta que reclama uma solução, exigindo do aplicador um verdadeiro exercício de sopesamento entre os princípios concorrentes no caso específico.

Saliente-se que não se trata de simples escolha, mas sim, de um ato de decisão vinculado às variações fáticas do caso, com o fito de encontrar a solução mais adequada.

Já Robert Alexy aponta alguns critérios para diferenciar regras e princípios, que em última análise, coincide com a apresentada por Dworkin. Alexy alega que os princípios são mandamentos de otimização. De qualquer modo, a determinação do peso de cada um levará em conta as condições de cada caso concreto.

Em verdade, é a índole qualitativa que difere as normas. Alexy sustenta que os princípios são normas que impõem que algo seja realizado na maior medida do possível, respeitadas as possibilidades reais e jurídicas existentes.

Sem discordar de Dworkin, Alexy sustenta que em caso de confronto de regras jurídicas com consequências opostas para a situação concreta, de tal sorte que essa oposição não possa ser eliminada mediante a inserção de uma cláusula de exceção, há de se entender como inválida ao menos uma das regras.

Portanto, a depender de sua validade, estas só podem ser aplicadas ou não, isto é, a decisão pela aplicação de uma ou outra regra é restrita à seara da validade.

Já perante a colisão de princípios, a decisão por um destes não elimina o outro. Os princípios impõem a concretização da melhor medida possível, respeitando-se os limites fáticos e jurídicos.

Relevante sublinhar que a distinção proposta por Alexy sobre regras e princípios não leva em conta o grau de fundamentalidade.

O princípio pode até ser um mandamento nuclear do sistema, um de seus pilares ou não, pois o que caracteriza a norma como princípio corresponde à estrutura e à forma de aplicação.

Alexy aponta que as regras jurídicas não encerram mandamentos de otimização e, sim, deveres definitivos. O objetivo de Robert Alexy com sua teoria sobre direitos fundamentais não é alcançar exatamente uma 
homogeneização de cada ordem jurídica fundamental. Seu objetivo, na verdade, é o de descobrir as estruturas dogmáticas e revelar os princípios e valores que se escondem atrás das codificações e da jurisprudência. Isto porque, em qualquer lugar que existam direitos fundamentais, colocam-se problemas semelhantes como, por exemplo, as diferenças estruturais entre os direitos sociais e os políticos (JÚDICE, 2007).

A guisa de exemplificação suponha que o tributo é criado por decreto do Chefe do Executivo Federal, quando, pela regra da legalidade em seara tributária, a exação deveria ser instituída mediante lei em sentido escrito (lei ordinária ou complementar, conforme o caso).

Assim, ou o tributo foi criado por lei em sentido estrito, sendo, portanto, neste aspecto válido, ou foi criado por meio de outro veículo normativo, pelo que será inválido. Não há meio-termo.

Nem sempre o afastamento da regra implica em sua invalidação e as regras atuam como concretizações ou desdobramentos dos princípios.

Quando uma regra figurar como materialização de um princípio que está em colisão com outro, o principio afastado também levará consigo as regras que lhes dá desdobramento normativo, sem que isso acarrete a exclusão dessas regras de ordem jurídica.

A aplicação das regras se restringe à dimensão da validade, ao passo que os princípios comportam a dimensão do peso, em razão do caráter prima facie destes últimos.

De revés, as regras, quando válidas, consubstanciam uma determinação fática e juridicamente possível, de modo que vale definitivamente o que a regra dispuser.

Portanto, uma vez declinados alguns elementos diferenciadores dessas normas jurídicas (regras e princípios) sem, contudo, ter a pretensão de exaustividade, cabe reiterar a atuação dos princípios constitucionais na acomodação da Constituição perante as novas demandas e interesses coletivos sem ocorrer a sua fragmentação formal.

Veja-se que, para Canotilho, a Constituição se caracteriza como sistema aberto na medida em que este possui uma estrutura dialógica, traduzida na capacidade de aprendizagem das constantes mudanças ocorridas na sociedade. Constituição como reserva de justiça: em vez de a problemática das expectativas de justiça se concentrar sobre todo o sistema social deslocava-se obsessivamente para a lei fundamental. 
A abertura da Constituição refere-se à abertura horizontal, caracterizadora da incompletude do sistema constitucional, de sua estrutura fragmentária. É a existência de regras e princípios que permite a compreensão do direito constitucional como um sistema aberto. Se o modelo jurídico estivesse formado apenas por regras, estaríamos restritos a um sistema fechado, com uma disciplina legal exaustiva de todas as situações, alcançando a segurança, mas impedindo que novas situações fossem abarcadas pelo sistema. Por outro lado, a adoção somente de princípios seria impossível, pois diante de tal indeterminação (sem a existência de regras precisas), o sistema mostrar-se-ia "falho de segurança jurídica e tendencialmente incapaz de reduzir a complexidade do próprio sistema" (CANOTILHO, 1998, p.1126).

Apesar da Constituição não ser um sistema normativo completo, é completável. Já o caráter aberto das normas constitucionais revela uma abertura vertical, o que permite conformação legislativa/concretizadora em razão de generalidade e indeterminação de muitas das normas componentes da Constituição.

Resta saber se a abertura da Constituição é capaz de possibilitar a busca e a materialização da Constituição por parte de sociedade aberta e pluralista.

A presença de normas principiológicas na Constituição traduz uma flexibilidade, ensejando a sua alteração mediante a interpretação constitucional. Tal processo pode ser compreendido como processo formal de mudança da Constituição.

É perceptível que a presença dos princípios jurídicos e cláusulas abertas nas Constituições proporcionam maior liberdade na interpretação judicial em razão do considerável grau de indeterminação e abstração de seus enunciados.

Evidentemente que o direito constitucional principiológico incrementa significativamente a criatividade do juiz constitucional, e apela para sua percepção sociológico-cultural das lides em apreciação. Isso decorre da circunstância de que quanto menor a densidade semântica do enunciado normativo a ser interpretado, maior o poder de criação jurídica pelo intérprete.

A imagem do "juiz" vinculado à lei resta enfraquecida diante da imagem "do juiz vinculado à Constituição". No lugar de submissão, o juiz encontra espaçosos horizontes para exegese do texto constitucional. É importante frisar a grande elasticidade semântica que é superior à maioria das disposições legais. Então, o juiz é forçado a ser livre e os princípios assumem papéis decisivos. A constituição é agora uma gramática aleatória (mas frise-se ainda gramática) fornecedora de regras mínimas garantidoras da própria integridade dos sistemas 
sociais interativos e de uma dimensão de justiça no seio da complexidade social.

O texto das normas jurídicas deve ser encarado como filtro com textura mais ou menos densa. O grau de porosidade (ou seja, de abertura e abstração) do texto normativo é indicado pelo número e pela diversidade das alternativas de interpretação que esse texto autoriza, isto é, das alternativas que podem passar pela "peneira" do próprio texto.

Quanto maior o número de interpretações diversas ou divergentes que podem ser sustentadas em relação a determinado texto normativo, menor será sua densidade normativa e vice-versa.

\section{CONCLUSÃO}

Conclui-se, assim, que o Direito Constitucional não pode ser definido apenas a partir do que está escrito na Constituição, pois seu texto exige a demarcação do conteúdo mediante sucessivos processos de concretização.

A evolução valorativa pode ser feita via interpretação, principalmente em razão do fato de que é da Constituição que todas as demais normas retiram seu fundamento de validade. Portanto, justifica-se a interpretação como fator de atualização da Constituição, sendo mecanismo de mutação constitucional, encontrando-se a Constituição em relação condicionadora e condicionante com as demais estruturas do Estado e da sociedade. A interpretação constitucional consiste num processo intelectivo por meio do qual enunciados linguísticos que compõem a constituição transformam-se em normas (princípios e regras constitucionais), isto é, adquirem conteúdo normativo.

A mudança da constituição (aliás, a doutrina não é pacífica com relação à terminologia adotada, pois ora cogita em mudança ou modificação da Constituição, ora aludindo aos vocábulos mutação constitucional) pode ocorrer formal ou informalmente. Altera-se formalmente quando o próprio texto constitucional é modificado por meio de reforma constitucional seja por meio de emenda ou revisão constitucional.

No entanto, informalmente altera-se a constituição pela interpretação, alvejando-se o significado da norma, mas não o seu texto. Interpretar as normas constitucionais significa (como toda a interpretação de normas jurídicas) compreender, investigar e mediatizar o conteúdo semântico dos enunciados linguísticos que formam o texto constitucional. A interpretação jurídica constitucional reconduz-se à atribuição de um significado a um ou vários símbolos linguísticos escritos na constituição. 
Para Hesse, a modificação constitucional acarreta a mudança literal do texto constitucional, ao passo que a mutação constitucional não afeta o texto e, sim, a concretização das normas constitucionais. Hesse (1991), inclusive, colocase em oposição às teses desenvolvidas por Ferdinand Lassale. Empenha-se em demonstrar que não há de se verificar uma derrota da Constituição quando colocamos a mesma em oposição aos fatores reais de poder demonstrados por Lassale. Existem intenções que podem ser realizadas e que permitem assegurar a força normativa da Constituição, mesmo que a submetamos a confrontos com os fatores reais de poder. A transformação das questões jurídicas em questões de poder, somente poderá será possível quando essas intenções não puderem atingir os seus objetivos.

A doutrina costuma fixar a diferença entre reforma constitucional e mutação constitucional. A primeira consistente em modificações constitucionais previstas no próprio texto constitucional (acréscimos, supressões e emendas), pelos processos por esta fixados para a reforma; já a segunda refere-se à alteração de significado da norma, por meio de interpretação judicial.

Afinal, a Constituição não determina a total organização da unidade política, mas tão somente consigna os princípios vetores de uma determinada coletividade.

Defende Konrad Hesse que a Constituição deve ser imperfeita e a incompleta e sempre sujeita às alterações históricas. E tal flexibilidade constitucional só é possível exatamente em função dos princípios constitucionais.

Assim, concretizam-se os direitos fundamentais através de interpretação constitucional. A constituição é a ordem jurídica fundamental do Estado; é o estatuto jurídico do político, onde há a pretensão de estabilidade e a pretensão de dinamicidade.

Ainda albergando o pensamento de Konrad Hesse a Constituição não só indica o que deve ficar aberto como determina com obrigatoriedade o que não deve ficar aberto.

E, com base na Constituição Federal Brasileira de 1988 o povo, enquanto titular do poder constituinte originário, decidiu que quanto aos direitos fundamentais, os princípios constitucionais devem permanecer abertos para dentro do tempo.

Não é paradoxal admitir que as Constituições rígidas devam possuir uma adequada flexibilidade capaz de acompanhar a dinâmica social. A Lex Mater deve disciplinar o poder político, além de consignar em seu corpo aqueles valores fundamentais consagrados em cada momento histórico pela sociedade como 
um todo e necessários a uma existência digna por parte dos cidadãos. Hesse realça a necessidade de superação de um isolamento entre norma e realidade, presente no pensamento constitucional do passado recente.

Cabe à Constituição apontar atribuições e competências do poder constituído, prover a disciplina territorial do poder e delimitar a estrutura do Estado/Governo.

Chegamos a uma Lei Maior sintética e não analítica, com aguda possibilidade de flexibilização principalmente pelo meio informal de interpretação.

As reformas constitucionais só devem ocorrer em momentos críticos, de instabilidade político-institucional.

Somente quando não mais funcionar a mutação constitucional é que deve ser realizada a mudança na Constituição.

Até o presente momento o texto constitucional brasileiro vigente já sofreu setenta emendas, o que confirma que não existe Constituição permanente, e repisa a indispensabilidade dos princípios delineadores, com o fito de dar os contornos gerais ao ordenamento jurídico e esculpir o modus de desenvolvimento político-administrativo no qual resta plasmado um caráter sintético com a preocupação de consolidar o respeito à dignidade da pessoa humana, a cidadania e ao Estado de Direito.

\section{REFERENCIAS}

BARROSO, Luís Roberto. Interpretação e aplicação da Constituição: fundamentos de uma dogmática constitucional transformadora. São Paulo: Saraiva, 1999.

BASTOS, Celso Ribeiro. Curso de Direito Constitucional. São Paulo: Saraiva, 1994.

. Hermenêutica e interpretação constitucional. São Paulo: Celso Bastos Editor/IBDC, 1997.

BASTOS, Celso Ribeiro e TAVARES, André Ramos. As tendências do Direito Público no limiar de um novo milênio. São Paulo: Saraiva, 2000.

BOBBIO, Norberto. Teoria generale del derecho. Tradução de José Guerrero R. 3. ed. Santa Fe de Bogotá : Editorial Temis, 1999. 
- Nicola Metteucci e Gianfranco Pasquino. Dicionário de Política. 5. ed. São Paulo: Editora UnB, 2004.

. A era dos direitos. Rio de Janeiro: Campus, 1992.

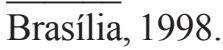

. Locke e o Direito Natural. Brasília: Editora Universidade de

. O Positivismo Jurídico: Lições de Filosofia do Direito.

São Paulo: Ícone, 1995.

. Sociedade e Estado na Filosofia Política Moderna. São Paulo: Ática, 1989.

BONAVIDES, Paulo. Curso de Direito Constitucional. São Paulo: Malheiros, 1994.

. A evolução constitucional do Brasil. Estud. av. [online]. 2000, vol.14, n.40, pp.155-176. Disponível em: $<$ http://dx.doi.org/10.1590/S010340142000000300016>.

CANOTILHO, José Joaquim Gomes. Direito Constitucional. Coimbra: Almedina, 1993.

. Constituição dirigente e vinculação do legislador: contributo para a compreensão das normas constitucionais programáticas. Coimbra: Coimbra Editora, 1994.

Almedina, 1998.

. Direito Constitucional e Teoria da Constituição. Coimbra:

CANOTILHO, José Joaquim Gomes e MOREIRA, Vital. Fundamentos da Constituição. Coimbra: Coimbra Editora, 1991.

CAVALCANTI, Eduardo Muniz Machado. Um estudo sobre a distinção clássica estabelecida pela doutrina entre regras e princípios jurídicos e uma nova perspectiva acerca do tema. Boletim Jurídico, Uberaba/MG, ano 4, n. 188. Disponível em: $<$ http://www.boletimjuridico.com.br/ doutrina/ texto.asp?id=1438>. Acesso em: 13 set. 2011.

COELHO, Inocêncio Mártires. Interpretação constitucional. Porto Alegre: Sérgio A. Fabris Editor, 1997. 
CRISTÓVAM, José Sérgio da Silva. A resolução das colisões entre princípios constitucionais. Jus Navigandi, Teresina, ano 8, n.62, 1 fev. 2003. Disponível em: $<$ http://jus.com.br/revista/texto/3682 $>$. Acesso em: 12 set. 2011.

DIMOULIS, DIMITRI. Positivismo Jurídico. In: GILMAR MENDES (org.) Introdução a uma teoria do direito e defesa do pragmatismo jurídicopolítico. 2.ed. São Paulo: 2006. v.2.

DWORKIN, Ronald. A mater of principle. Cambridge: Havard University Press, 1985.

ENTERRÍA, Eduardo García de. Hermenêutica e supremacia constitucional. RDP, v.77, n.19, jan/mar/1986.

HÄBERLE, Peter. Hermenêutica constitucional. A sociedade aberta dos intérpretes da Constituição: contribuição para a interpretação pluralista e " procedimental " da Constituição. Tradução de Gilmar Ferreira Mendes. Porto Alegre: Sérgio A. Fabris Editor, 1997.

HESSE, Konrad. A Força normativa da Constituição. Tradução de Gilmar Ferreira Mendes. Porto Alegre: Sérgio A. Fabris Editor, 1991.

JÚDICE, Mônica Pimenta. Robert Alexy e a sua teoria sobre os principios e regras. Disponível em: <http://www.conjur.com.br/2007mar-02/robert_alexy_teoria_principios_regras $>$. Acesso em: 15 dez. 2011.

KELSEN, Hans. O Estado como integração: um confronto de princípios. São Paulo: Martins Fontes, 2003.

. Teoria Pura do Direito. 6.ed. São Paulo: Martins Fontes, 1998.

LARENZ, Karl. Metodologia da ciência do direito. 2.ed. Lisboa:

Fundação Calouste Gulbenkian, 1983.

LEITE, George Salomão. Dos Princípios Constitucionais. 2.ed. rev., atual. e ampl. São Paulo: Editora Método, 2008.

(coord.) Constituição e efetividade constitucional. Salvador: Juspodivm, 2008. 
MARINONI, Luiz Guilherme. Teoria Geral do processo. São Paulo: Editora Revista dos Tribunais, 2006.

MENDES, Gilmar Ferreira. Jurisdição constitucional. São Paulo: Saraiva, 1999.

. Direitos fundamentais e controle de constitucionalidade: estudos de direito constitucional. São Paulo: Celso Bastos Editor/IBDC, 1998.

MENDES, Gilmar Ferreira, COELHO, Inocêncio Mártires e BRANCO, Gustavo Gonet. Hermenêutica constitucional e direitos fundamentais. Brasília: Brasília Jurídica, 2000.

MIRANDA, Pontes de. Comentários à Constituição de 1967. São Paulo: Editora Revista dos Tribunais, 1970.

PEIXINHO, Manoel Messias. A interpretação da Constituição e os Princípios Fundamentais. Elementos para uma hermenêutica constitucional renovada. 3 ed. Rio de Janeiro: Lumen Júris, 2003.

RADBRUCH, Gustav. Filosofia do Direito. Coimbra: Armênio Amado, 1979.

RADBRUCH, Gustav; SCHIMDT, Eberhard, WELZEL, Hans. Derecho injusto y derecho nulo. Madrid : Aguilar, 1971.

. Arbitrariedad Legal y Derecho Supralegal. Argentina: Ed. Abeledo-Perrot, 1962.

REALE, Miguel. Filosofia do direito. 13. ed. São Paulo: Saraiva, 1990.

. Nova fase do direito moderno. 2. ed. São Paulo: Saraiva, 1998.

ROCA, Javier Garcia. Sobre la teoria constitucional de Rudolf Smend. Revista e estúdios políticos. Madrid: Centro de estúdios constitucionales, 1998.

SARMENTO, Daniel. Ponderação de interesses na Constituição Federal. 3.ed. Rio de Janeiro: Lumen Juris, 2003. 
SGARBI, Adrian. Hans Kelsen (Ensaios Introdutórios). Rio de Janeiro: Lumen Juris, 2006.

SILVA, José Afonso da. Curso de Direito Constitucional Positivo. São Paulo: Malheiros, 1998.

SOIBELMAN, Leib. Enciclopédia Jurídica Eletrônica. São Paulo:

Saraiva, 1997.

STRECK, Lenio Luiz. Hermenêutica jurídica e(m) crise: uma exploração hermenêutica da construção do Direito. Porto Alegre: Livraria do Advogado, 2000 .

TEMER, Michel. Elementos de Direito Constitucional. São Paulo: Malheiros, 1999.

VÁSQUEZ, María Isabel Azaretto de. Arbitrariedad Legal y Derecho Supralegal. Abeledo-Perrot: Buenos Aires, 1962.

Recebido em: 2011-09-25 Aprovado para publicação em: 2012-09-13

Como citar: LEITE, Gisele; HEUSLER, Denise. Considerações principiológicas sobre a Constituição Federal Brasileira Scientia Iuris, Londrina, v.16, n.1, p.45-66, jul.2012. DOI: $10.5433 / 2178-8189.2012 \mathrm{v} 16 n 1 \mathrm{p} 45$. 